\title{
Duodenal mucosal bicarbonate secretion in man. Stimulation by acid and inhibition by the alpha $_{2}-$ adrenoceptor agonist clonidine
}

\section{KNUTSON AND G FLEMSTRÖM}

From the Department of Surgery, University Hospital and Department of Physiology and Medical Biophysics, Uppsala Biomedical ('entre, Uppsala, Sweden

summary A multi-channel small diameter tube was used to study the secretion of bicarbonate by $3 \mathrm{~cm}$ long segments of the proximal duodenum isolated between balloons. The tube had an outer diameter of $5 \cdot 3 \mathbf{~ m m}$ and two central and four smaller, peripheral channels. Measurements of infused phenol red, ${ }^{4} \mathrm{C}$-PEG and vitamin $\mathrm{B}_{12}$ and of trypsin activity were performed to rule out contamination of the perfusate by gastric and pancreatic secretions. Basal secretion of bicarbonate by the duodenal mucosa in healthy subjects varied between 135 and $220 \mu \mathrm{mol} / \mathrm{cm}$ of intestine per hour. Perfusion of the lumen with acid $(100 \mathrm{mM} \mathrm{HCl}$ for five minutes) increased the secretion to $>400 \mu \mathrm{mol} / \mathrm{cm} / \mathrm{h}$ and the $\alpha_{2}$-adrenoreceptor agonist clonidine $\left(150 \mu \mathrm{g}\right.$ iv) decreased the $\mathrm{HCO}_{3}{ }^{-}$ secretion by $70 \mu \mathrm{mol} / \mathrm{cm} / \mathrm{h}$. Clonidine simultaneously reduced the mean arterial blood pressure and plasma noradrenaline concentration, but did not affect the plasma glucose or adrenaline concentration. Duodenal bicarbonate secretion is important in the protection of this mucosa against acid discharged from the stomach. Increased sympathetic activity may, by inhibiting the bicarbonate secretion, decrease the protection in proximal duodenum in man and facilitate ulceration.

Gastric and duodenal mucosa secretes bicarbonate to the lumen by processes that depend on tissue metabolism.' The secretion increases the $\mathrm{pH}$ in the mucus gel adherent to the epithelial surface and is important in the protection against luminal acid. Acid in the lumen is a potent stimulus of the bicarbonate secretion, but a decrease in the exposure to acid by longterm treatment with potent acid inhibitory drugs does not affect the duodenal secretion in rats. Electrical stimulation of the vagal nerves in cats and rats increases the secretion in both the stomach and duodenum, while administration of $\alpha_{2}$-adrenoceptor agonists or electrical stimulation of the splenchnic

Address for correspondence: 1 ars knutson. MII). Dept of Surgery. University Hospital. S-751 \$5 Uppalia. Sweden.

sccepted for publication 5 spril loses nerves has an inhibitory effect ${ }^{34}$. Elicitation of sympathetic reflexes results in similar inhibition of the duodenal secretion. Evidence for autonomic nervous influence on gastric and duodenal secretion has also been obtained in man: sham feeding has been found to be a stimulant of both gastrich and duodenal" mucosal bicarbonate secretion in healthy voluntecrs.

A method for determination of bicarbonate secretion in the proximal duodenum in man, was recently described by Isenberg and his collaborators using a multilumen tube with two or three balloons to occlude the duodenal lumen." "I" We have modified this technique by using a small diameter tube and report rates of basal and acid stimulated bicarbonate secretion in healthy voluntecrs. The inhibition of secretion in humans by the $\alpha_{2}$-adrenoceptor agonist clonidine is also described. 


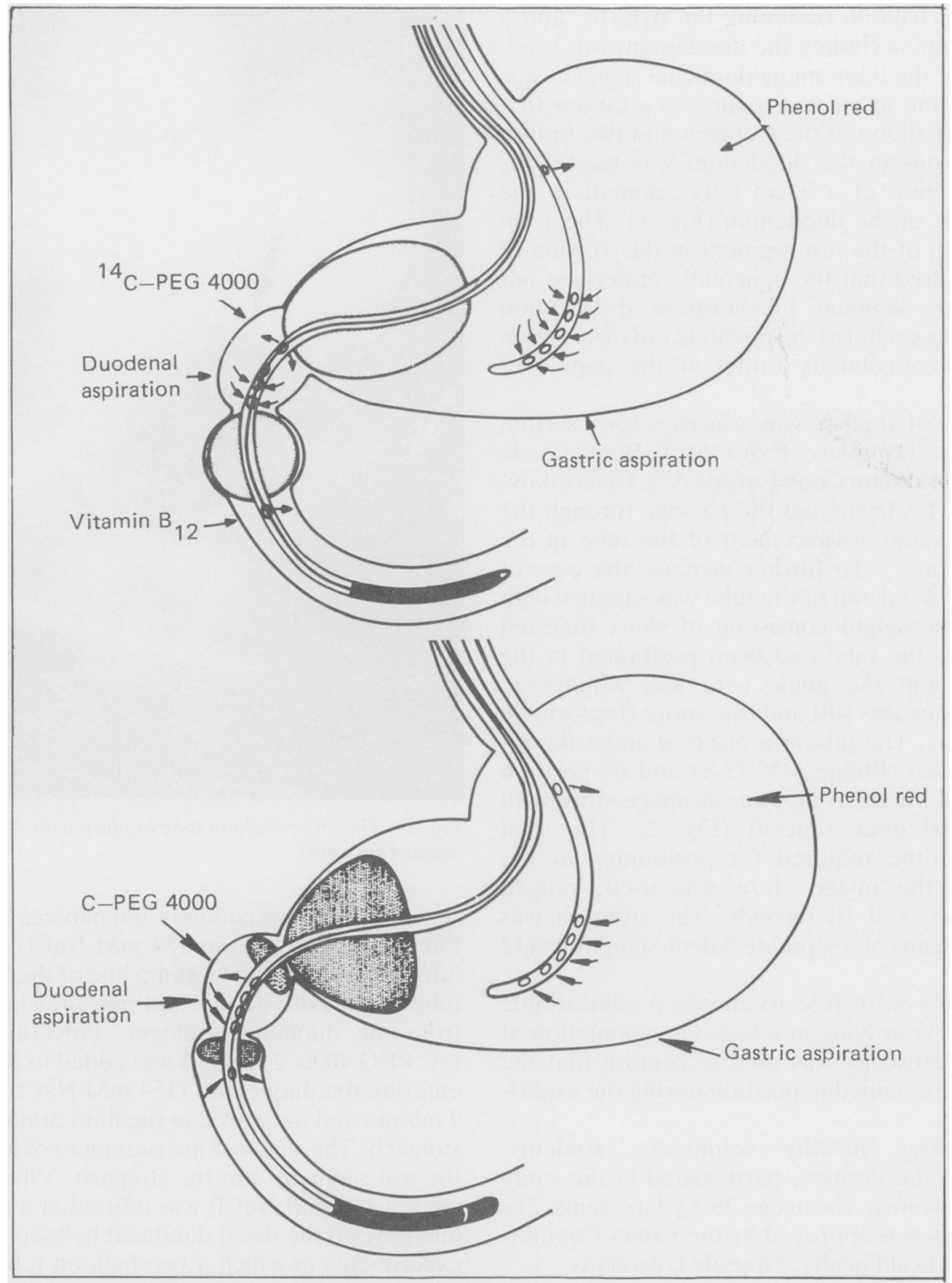

Fig. 1 The first part of the study was performed with a wo balloon tube. Later a pearshaped balloon proximal to and a button shaped balloon just distal to the pylorus anchored the segment. The third balloon was also button-shaped so as not to interfere with the pancreatic biliary outlet.

\section{Methods}

TUBE DESIGN AND PI.ACEMENT

An intestinal tube of polyvinylchloride with an outer diameter of 16 French $(5 \cdot 3 \mathrm{~mm})$, containing six channels and provided with two to three balloons, was constructed. The small diameter made it possible to introduce the tube through either one nostril or the mouth. There were two wide channels in the centre of the tube for infusion and removal of fluid. Four smaller peripheral channels were used for injection of air into the balloons and for administration of marker substances.

In the first seven experiments a tube with one 
larger gastric balloon occluding the pylorus, and a smaller balloon occluding the duodenum, was used. The length of the intervening duodenal segment was $4 \mathrm{~cm}$. Later and in most experiments a tube with a pear shaped balloon in the stomach and two button shaped balloons in the duodenum was used. This ensured isolation of a $3 \mathrm{~cm}$ long segment in the proximal part of the duodenum (Fig. 1). The $1 \mathrm{~cm}$ shorter length of the test segment in this version of the tube ensured that the pancreatic outlet was not included in the segment. Furthermore, the location of the balloons excluded the possibility of obstruction of the pancreaticobiliary outlet at the papilla of Vater.

A Teflon coated guide wire was used for insertion of the tubes (Amplatz Extra Stiff Wire Guide $\varnothing 0 \cdot(03.5$ inch, William Cook Europe A/S, Bjacreskov, Denmark). This facilitated the passage through the pylorus and rapid advancement of the tube in the distal direction." : To further increase the ease of insertion the distal end of the tube was supplied with an $8 \mathrm{~cm}$ long weight consisting of short tungsten plates. When the tube had been positioned in the desired segment the guide wire was withdrawn, making the tube less stiff and thus more comfortable for the subject. The tube was inserted under fluoroscopic guidance (Philips BV 21-S) and its position was recorded on video tape or an image store with automatic $200 \mathrm{msec}$ shut-off (Fig. 2). The total fluoroscopic time required for positioning of the tube, when the image store was used, ranged between three and 10 seconds. The stomach was drained by means of a separate Salem-sump tube (12 French).

The subjects were free to choose a comfortable position, sitting or lying in a bed. On completion of the study fluoroscopy was used to confirm that the balloons had remained in position during the experiment.

Twenty three healthy volunteers, students, medical staff and firemen, participated in the study ( 17 men, six women, mean age 28.5 years, range $21-$ 47). The study was approved by the Ethics Committec of the Medical Faculty, Uppsala University.

PI:RFUSIONS AND ANAIYYSES

The gastric balloon was inflated with $30 \mathrm{ml}$ air and the duodenal balloons with $5-15 \mathrm{ml}$. The temperature of the solutions was $37^{\circ} \mathrm{C}$ and they were infused into the stomach or duodenum by syringe pumps (Model 355. Sage Instruments, Orion Rescarch Inc, Cambridge, Mass, USA). The effluent was collected from the stomach by suction and from the duodenal segment by gravity drainage. Non-absorbable markers were used to check for any leakage of perfusate from the duodenal segment and to exclude entrance into this

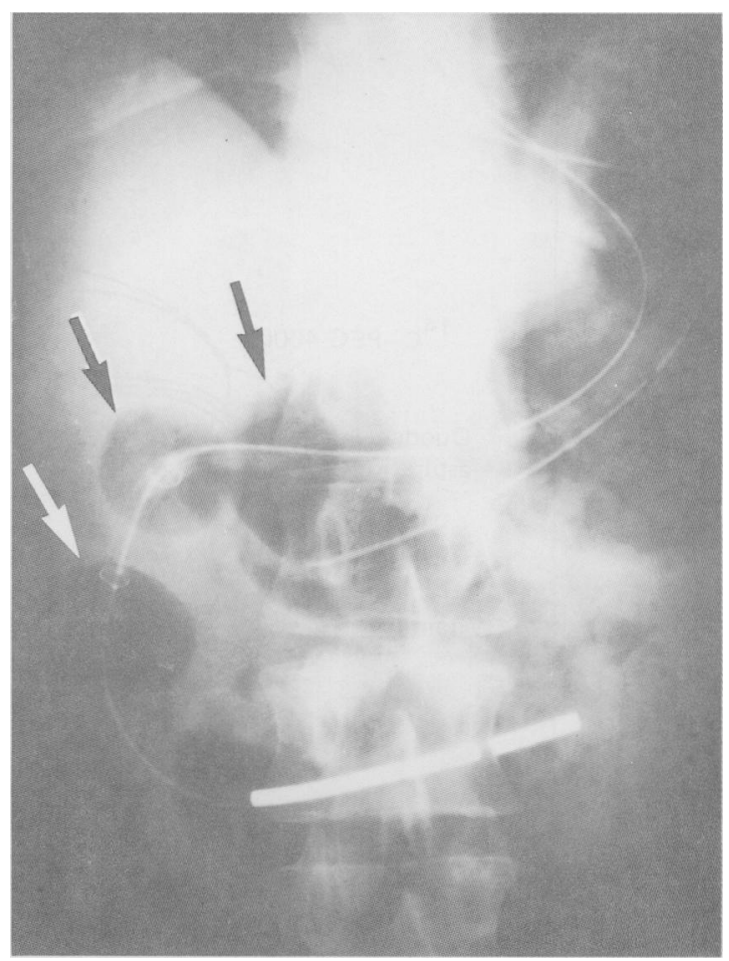

Fig. 2 The three-balloon tube in place with the balloons inflated (arrows).

segment of gastric contents and pancreatic secretion. Phenol red $(50 \mathrm{mg} / \mathrm{l}$ in $154 \mathrm{mM} \mathrm{NaCl})$ was infused into the stomach by the sump line of the Salem-sump tube at a rate of $1 \mathrm{ml} / \mathrm{min}$ and measured in the effluent from the duodenal segment. Polyethylene glycol $\left({ }^{1+} \mathrm{C}\right.$ PEG $\left.4000,2 \cdot 5 \mu \mathrm{Ci} / \mathrm{l}\right)$ was added to the perfusate entering the duodenum $(154 \mathrm{mM} \mathrm{NaCl})$ at a rate of $2 \mathrm{ml} / \mathrm{min}$ and measured in the fluid drained from the stomach. This enabled measurement of leakage from the test segment into the stomach. Vitamin $B_{12}$ (40) $\mathrm{mg} / \mathrm{l}$ in $154 \mathrm{mM} \mathrm{NaCl}$ ) was infused at a rate of $1 \mathrm{ml} /$ min beyond the distal duodenal balloon in the seven experiments in which a two-balloon tube was used. Its concentration in the effluent from the duodenum was determined, making it possible to quantitate flux from the intestine into the test segment. Vitamin $B_{12}$ was not infused when the three balloon tube was used, that channel being used for filling the third balloon with air. To further rule out the possibility of contamination of the segment by pancreatic secretion, the trypsin content of the duodenal effluent was always measured. The presence of ${ }^{1+} \mathrm{C}-\mathrm{PEG}$ in the test segment and measurement of its concentration in the effluent also permitted calculation of the volume of the secretion by the 
test segment by means of standard equations for dilution. ${ }^{13}$

The concentration of bicarbonate in $100 \mu \mathrm{\mu l}$ samples from the duodenal effluent was determined in triplicate (Corning 965 Carbon Dioxide Analyzer, Corning Ltd, Halstead, England). Before analysis, samples were gassed with $\mathrm{N}_{2}$ for five minutes to remove dissolved $\mathrm{CO}_{2}$. The analyser was calibrated daily against known concentrations of bicarbonate. The use of the Corning Analyzer in the $\mathrm{HCO}_{3}{ }^{-}$ analyses provided very good accuracy (Fig. 3). ${ }^{1+}$ ${ }^{14} \mathrm{C}$-PEG in duplicate samples was determined by liquid scintillation for 15 minutes (LKB Rackbeta II, Wallac Oy, Turku, Finland). Phenol red was measured spectrophotometrically at $520 \mathrm{~nm}$ (Hitachi model 101, Hitachi Ltd, Tokyo, Japan) after alkalinisation to $\mathrm{pH} 11$ with $\mathrm{Na}_{3} \mathrm{PO}_{4}$ buffer. ${ }^{15}$ Vitamin $\mathrm{B}_{12}$ was measured spectrophotometrically at $361 \mathrm{~nm}(\mathrm{pH}$ 6.7) after removal of the bile salts by washing in chloroform. ${ }^{\text {th }}$ Trypsin was measured by a $\mathrm{pH}$-stat method with TAME (n-p-tosyl-l-arginine methyl ester) as substrate. ${ }^{17 \mathrm{Is}}$

EXPERIMENTAL PROTOCOI.

Studies were carried out on healthy volunteer subjects after an overnight fast. Ranitidine $(150 \mathrm{mg}$, Zantac $^{\circledR}$, Glaxo, Greenford, England) was given orally one hour before the experiment to suppress gastric acid secretion. As shown previously this histamine $\mathrm{H}_{2}$ blocker does not affect either basal or acid stimulated duodenal bicarbonate secretion." After rinsing of the segment by perfusion with isotonic $\mathrm{NaCl}$ for 30 minutes, the effluent was collected at 15 minute intervals for analyses. Basal bicarbonate secretion alone was studied in some experiments. Before examining the effects on the secretion of luminal acid, steady state basal secretion. was recorded for four sampling periods. Twenty millilitres of $100 \mathrm{mM} \mathrm{HCl}$ was then instilled into the segment and removed after five minutes by gentle flushing with isotonic $\mathrm{NaCl}$. The latter flushing was continued during the following 10 minutes or until the $\mathrm{pH}$ was neutral again. Acid in the segment was thus removed and the $\mathrm{HCO}_{3}^{-}$measurements were not restarted until neutrality had been restored.

The effects of the $\alpha_{2}$-adrenoceptor agonist clonidine were studied after recording of steady state rates of basal secretion for three 15 minute periods. Ten millilitres of isotonic $\mathrm{NaCl}$ was then given intravenously as a placebo. After another two 15 minute periods, $150 \mu \mathrm{g}$ clonidine (Catapresan ${ }^{(\hat{K})}$, Boehringer-Ingelheim, Ingelheim, FRG) was slowly injected intravenously in 10 subjects. The blood pressure was monitored every 15 minutes throughout these experiments. Plasma adrenaline, noradenaline and glucose concentrations were measured before

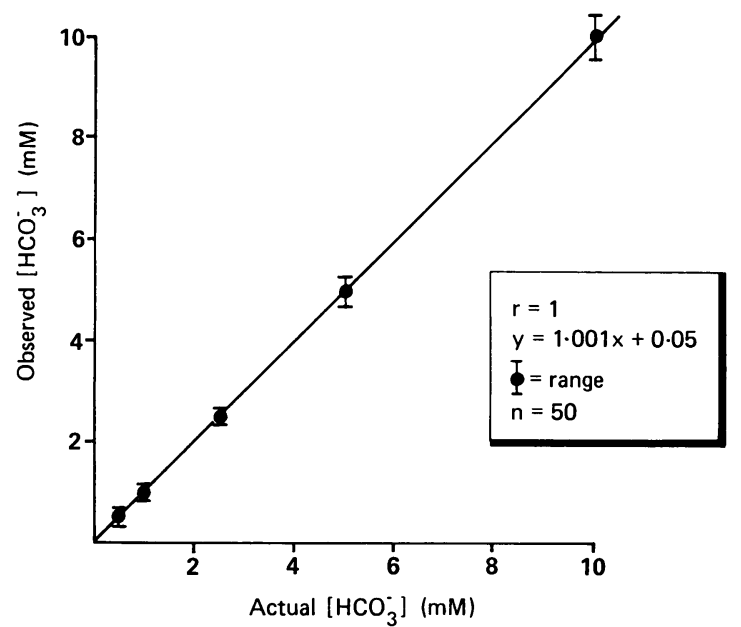

Fig. 3 Validation of Corning 96.5 Carbon Diovide Analyzer. in vitro. Observed results are compared with actual $\mathrm{HCO} \mathrm{C}_{3}$ values $(n=50)$. Vertical bars represent range.

and 30) and 60 minutes after the injection of clonidine.

The results are expressed as means (SEM). The two tailed Student's $t$ test for paired values was used for testing the statistical significance of differences. A $p$ value $<0.05$ was regarded as significant.

\section{Results}

A good correlation between the volume infused and the effluent collected was a mandatory test of the isolation of the segment. The volume infused into the duodenal test segment was $30 \mathrm{ml} / 15$ minute period. The mean volumes recovered in each group of experiments are listed in the Table and the mean recovery of infused ${ }^{14} \mathrm{C}$-PEG was $98 \cdot 1(2 \cdot 5) \%$. A small amount of gastric secretion entered the duodenal segment, as detected by the presence of phenol red (mean amount $1 \cdot 7(0 \cdot 1) \%$ of that in the stomach). Special care was taken to avoid contamination of the

Table Validation of methods

\begin{tabular}{|c|c|c|c|}
\hline & $\begin{array}{l}\text { Effluc'nt } \\
\text { volume }(\mathrm{ml})\end{array}$ & $" C-P E C ; "$ & Pho'nol red $\%$ \\
\hline $\begin{array}{l}\text { Basal HC( })_{3} \text { secretion } \\
(n=7)\end{array}$ & $28 \cdot 3(1 \cdot 7)$ & $95.5(5.6)$ & $1 \cdot 4(() \cdot 2)$ \\
\hline Acid stimulation $(n=6)$ & $31 \cdot 2(1 \cdot 1)$ & $95.7(4.2)$ & $1 \cdot+(0 \cdot 3)$ \\
\hline Clonidine $(n=10)$ & $28 \cdot(1)(1.3)$ & $99 \cdot 8(.3 .6)$ & $2 \cdot 0(0 \cdot 2)$ \\
\hline
\end{tabular}

The effluent volume is the amount collected from the segment in each 1.5 minute period after infusion of $30 \mathrm{ml}$ isotonic $\mathrm{NaCl}$ solution "C-PEG and phenol red are the amounts of these nonabsorbable markers collected in the effluent from the segment. "C-PE( $\mathrm{w}$ as infused into the segment and phenol red wats infused into the stomach. 


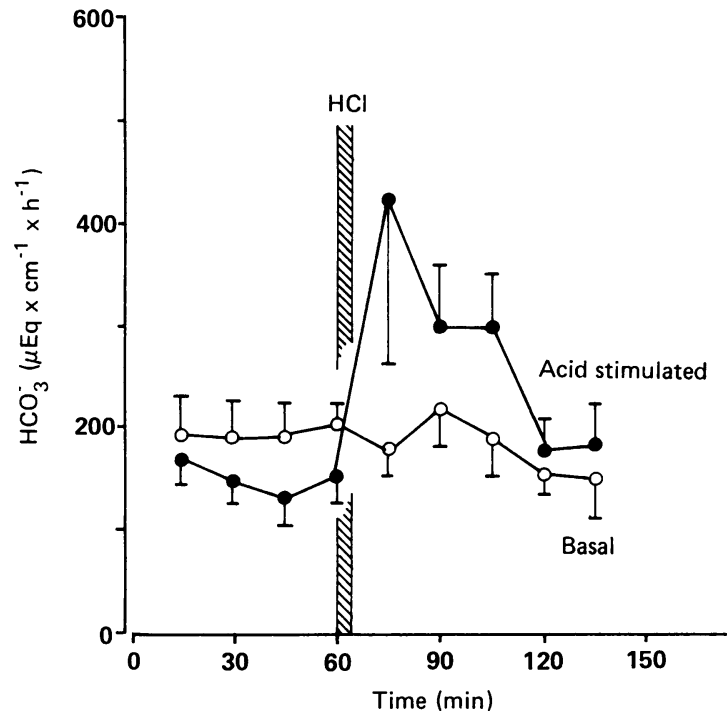

Fig. 4 Basal bicarbonate secretion was determined and found to be stable in healthy subjects during a period of 150 min (unfilled circles, $n=7$ ). Intraluminal acid $(100) \mathrm{mM} \mathrm{HCl}$ for 5 min, $n=6)$ increased the $\mathrm{HC}^{\prime} \mathrm{O}_{3}-$ secretion to $>400$ umol/cm/h $(p<0 \cdot 02)$. Mean values $(S E M)$ are presented.

segment with pancreatic or biliary secretion, since these contain bicarbonate. Only very small amounts of vitamin $B_{12}$, which was infused distal to the duodenal segment, were detected in the segment (mean $0.98(0.3) \%$ of the concentration infused) in the first seven experiments in which the two balloon tube was used. $B_{12}$ was not infused in the experiments with the three balloon tube. Similarly, the concentration in the segment of trypsin secreted by the pancreas was very low $(0 \cdot 44(0 \cdot 17) \mathrm{U} / \mathrm{ml}=37 \cdot 6(15 \cdot 3)$ nkat/l, ${ }^{1 .}$ confirming the efficiency of the distal balloon in preventing contamination of the segment. Now and then the duodenum showed a tendency to 'telescoping'; that is, the intestine and tested segment shortened causing inclusion of the biliary-pancreatic outlet in the segment. In such cases it was not possible to readjust the segment and the experiment was terminated. With the three balloon tube this was only a minor problem.

BASAL SECRETION AND STIMUI.ATION BY ACID The segment was continuously perfused with isotonic $\mathrm{NaCl}$ solution for 150 minutes in seven subjects (Fig. 4). The basal rate of duodenal bicarbonate secretion was $180 \cdot 5(8 \cdot 2) \mu \mathrm{mol} / \mathrm{cm} / \mathrm{h}$.

Instillation into the segment of $20 \mathrm{ml} 100 \mathrm{mM} \mathrm{HCl}$ decreased the $\mathrm{pH}$, which was 2 after five minutes. The acid was then removed. This exposure strongly stimulated the bicarbonate secretion, which

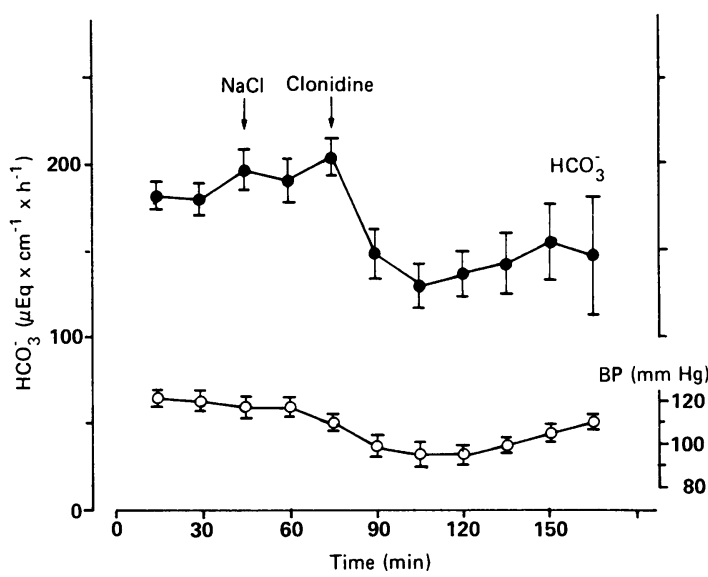

Fig. 5 Iv placebo $(10 \mathrm{ml} 154 \mathrm{mM} \mathrm{NaCl})$ did not alter the duodenal $\mathrm{HCO}_{3}^{-}$secretion but clonidine $(150 \mu \mathrm{g})$ decreased this secretion $(p<0 .(0) 5)$ and also the mean arterial blood pressure $(p<0 \cdot 001)$ and plasma noradrenaline concentration $(p<0 \cdot(05)$. Mean $($ SEM) are presented $(n=10)$.

increased to $>400 \mu \mathrm{mol} / \mathrm{cm} / \mathrm{h}(\mathrm{p}<0 \cdot() 2$, Fig. 4$)$. It should be noted that the bicarbonate secretion was not measured until the $\mathrm{pH}$ had returned to normal that is, 10 minutes after termination of the stimulation. The secretion declined to the pre-exposure value during the following 45 minutes.

INHIBITION BY INTRAVENOUS CLONIDINE: Intravenous injection of placebo $(\mathrm{NaCl}$ alone $)$ did not affect the basal secretion of bicarbonate. Clonidine $(150 \mu \mathrm{g})$, on the other hand, decreased the secretion by $55 \mu \mathrm{mol} / \mathrm{cm} / \mathrm{h}$ in the first 15 minute period after injection and by a further $15 \mu \mathrm{mol} / \mathrm{cm} / \mathrm{h}$ $(p<0.05)$ in the second 15 minute period (Fig. 5). The bicarbonate secretion then remained at a low level throughout the rest of the experiment. The blood pressure had decreased from $120(8) 92(6) \mathrm{mmHg}$ after 30 minutes $(\mathrm{p}<0 \cdot(001)$. The basal plasma noradrenaline concentration was $3 \cdot 2(0 \cdot 5) \mathrm{nM}$ and this had declined to $1 \cdot 2(0 \cdot 3) \mathrm{nM}(\mathrm{n}=3) 30$ minutes after the clonidine injection $(\mathrm{p}<0 \cdot(05)$. The plasma adrenaline concentration (basal and after 30 minutes $<0.03 \mathrm{nM}, \mathrm{n}=3$ ) was not affected and nor was the blood glucose concentration (basal $4.8(0.4) \mathrm{mM}$, after 30 minutes $4 \cdot 7(0.5) \mathrm{mM}, \mathrm{n}=7)$. Clonidine had a mild sedative effect and many subjects fell asleep after the injection.

\section{Discussion}

Results from studies in experimental animals indicate that the alkaline secretion by the duodenal mucosa is important in the protection of this epithelium against 
acid discharged from the stomach.' The secretion of bicarbonate is stimulated by the presence of acid in the lumen ${ }^{11}$ and deficits in basal secretion as well as in the response to acid have been observed in patients with chronic ulcer disease." In line with the latter deficit, it has been reported that when exposed to acid the duodenum in such patients has a significantly lower ability to maintain neutrality in the mucus gel at the mucosal surface. "I One aim of the present study was to modify and evaluate the technique for isolation and perfusion of duodenal segments described by Isenberg and collaborators." An easily introducible small diameter tube system was developed. The rates of basal secretion by the proximal duodenum found in our experiments (mean 180.5 and range 135-220 $\mu \mathrm{mol}$ base per $\mathrm{cm}$ of intestine and hour, $\mathrm{n}=70$ ) are almost identical to those reported by Isenberg.

The previous observation that a low $\mathrm{pH}$ in the lumen stimulates alkaline secretion by the duodenal mucosa in humans was confirmed in the present study, though the magnitude of the stimulation seems somewhat smaller. It should be noted in this context that no analyses of acidified perfusates were performed in the present experiments and that only the concentrations of $\mathrm{HCO}_{3}^{-}$per se (in contrast with $\mathrm{HCO}_{3}{ }^{-}$plus dissolved $\left.\mathrm{CO}_{2},{ }^{*}\right)$ were measured. $\mathrm{CO}_{2}$ is formed from $\mathrm{HCO}_{3}{ }^{-}$during reaction with acid and the duodenal (but not the gastric) mucosa has a high permeability to $\mathrm{CO}_{2} .^{.12}$ : Rapid diffusion of $\mathrm{CO}_{2}$ from the lumen into the tissue apparently decreases the rate of bicarbonate secretion as judged by measurements of perfusate $\mathrm{PCO}_{2}$, and the results might be influenced by variations in the permeability to $\mathrm{CO}_{2}$ rather than in mucosal bicarbonate secretion.

Special care was taken in the present study to remove acid instilled into the segment and measurement of bicarbonate in the effluent after exposure to acid was not restarted until neutrality had been attained. Our choice of method avoids the possibility that diffusion of $\mathrm{CO}_{2}$ from the tissue into the lumen will increase the secretion as measured at a neutral luminal $\mathrm{pH}$. Its disadvantage is that the bicarbonate secretion during or immediately after acid exposure cannot be measured. The results provide clear evidence that, as in other species, luminal acid is a stimulant of the duodenal bicarbonate secretion in man. The magnitude of the response to acid might be greater than could be recorded here.

Leakage of pancreaticobiliary secretions containing bicarbonate into the studied duodenal segment is a possible source of error but this must have been negligibly small, as only small amounts of vitamin $B_{12}$, which was infused distal to the segment, or of trypsin, which is secreted by the pancreas, were detected in the effluent. Distension of the small intestinal wall increases its secretion of fluids and electrolytes and also its motility. These effects are mediated by the enteric nervous system, which has been observed to influence bicarbonate secretion by the gastroduodenal mucosa in a similar way.- The possibility that the distended balloons might have stimulated the duodenal secretion could not be avoided in the present study. This disadvantage was small, however, compared with the contamination of the effluent in an open system by gastric contents or pancreatic juice. It has been observed in dogs and $\operatorname{man}^{2 n}=$ that the basic duodenal bicarbonate secretion varies in phase with the motor (myoelectric) activity, with an increase in secretion during phase III of the migratory motor complex. Manometry was not performed in the present study, but no periods with increased basal secretion were observed (Fig. 3).

The sympathetic influence on duodenal mucosal bicarbonate secretion has previously been studied in anaesthetised animals. Intravenous administration of $\alpha_{2}$-adrenoceptor agonists, electrical stimulation of the splanchnic nerves or elicitation of sympathetic reflexes potently inhibited the secretion in the cat and rat. ${ }^{+2 x}=1$ Infusion of the $\alpha_{2}$-agonist clonidine $(15 \mu \mathrm{g} /$ $\mathrm{kg} / \mathrm{h}$ ) in the rat (unpublished data), or splanchnic nerve stimulation in this species ${ }^{\text {in }}$ also decreased the ability of the duodenal mucosa to respond to luminal acid ( $\mathrm{pH} 2$ for $10 \mathrm{~min}$ ) with a rise in bicarbonate secretion. The $\alpha_{1}$-agonist phenylephrine in contrast has been found to be a weak stimulant." Inhibition of bicarbonate secretion has also been observed in some gastrointestinal tissues in vitro, including mucosac isolated from the frog gastric fundus ${ }^{31}$ and the rabbit ileum. "2 This suggests that adrenoceptor agonists and antagonists affect the secretion by effects on the enterocytes or possibly on local nervous tissue. Anaesthetic agents or isolation procedures may, however, profoundly modulate the response to neurohumoral stimuli. Such effects of anaesthesia have recently been reported with respect to alkaline secretion by the rabbit duodenum."

It was thus of considerable interest to examine the influence of an adrenergic agent on the duodenal mucosal bicarbonate secretion in unanaesthetised human subjects. It was shown in the present study that clonidine, an $\alpha_{2}$-receptor agonist, inhibits the secretion in man. The drug $(150 \mu \mathrm{g})$ decreased the plasma noradrenaline concentration but did not affect the blood glucose. This finding strongly suggests that as in animals, the duodenal mucosal alkaline secretion and protection in man are under $\alpha_{2}$-adrenergic inhibition. This is interesting in view of the observations that in duodenal uleer patients the plasma concentrations of catecholamines and the urinary output of their metabolites are increased. ${ }^{4}$ is Furthermore, it has been reported that splanchnico- 
tomy ameliorates stress induced ulceration in animals, ${ }^{36}$ and studies of the longterm sympathetic influence on mucosal protection could provide valuable information.

We wish to thank Drs Jon Isenberg, Daniel Hogan, Michacl Koss, and Arturo Ballesteros, San Diego Medical Center for valuable discussions and technical advice, Dr Frank Nicklasson, Department of Clinical Chemistry, Uppsala University, for performing the catecholamine determinations and Lillemor Ek and Carina Nimbratt for skilful technical assistance. The study was supported by grants from the Tore Nilsson Foundation, the Swedish Life Insurance Companies' Board for Medical Research, Pharmacia AB, Hässle AB, and the Swedish Medical Research Council (project No 04X-3515). Studies at the Division of Gastroenterology, San Diego Medical Center, USA were made possible by grants from The Swedish Society of Medicine and Glaxo Sweden AB.

\section{References}

1 Flemström G. Gastric secretion of bicarbonate. In: Johnson LR, Christensen J, Jackson MJ, Jacobson ED, Walsh JH, eds. Physiology of the gastrointestinal tract. Second Edition. New York: Raven Press, 1987: 101129.

2 Knutson L, Flemström G, Gustavsson S, Jedstedt G. Lönnerholm $\mathrm{G} . \mathrm{HCO}_{3}$ secretion in rat duodenum after treatment with omeprazole and ranitidine. Scand $J$ Gastroenterol 1987; 22: 87-90.

3 Nylander O, Flemström G, Delbro D, Fändriks L. Vagal influence on gastroduodenal $\mathrm{HCO}_{3}^{-}$secretion in the cat in vivo. Am J Physiol 1987; 252: 522-8.

4 Fändriks L, Jönson C, Nylander O. Effects of splanchnic nerve stimulation and of clonidine on gastric and duodenal $\mathrm{HCO}_{3}-$ secretion in the anaesthetized cat. Acta Physiol Scand 1987; 130: 251-8.

5 Jönsson G, Fändriks L. Bleeding inhibits vagally induced duodenal $\mathrm{HCO}_{3}{ }^{-}$secretion via activation of the splanchnic nerves in anaesthetized rats. Acta Physiol Scand 1987; 130: 259-64.

6 Forssell H. Stenqvist B, Olbe L. Vagal stimulation of human gastric bicarbonate secretion. Gastroenterology 1985: 89: $581-6$.

7 Feldman $\mathrm{M}$. Gastric $\mathrm{H}^{\prime}$ and $\mathrm{HCO}_{3}$ secretion in response to sham feeding in humans. Am J Physiol 1985: 248: $188-91$.

8 Ballesteros MA, Hogan DL, Koss MA. Chen HS, Isenberg JI. Vagal stimulation of human duodenal bicarbonate secretion (DBS) acts by non-cholinergic mechanisms [Abstract]. Gastroenterology 1988; 94: A20.

9 Isenberg JI. Hogan DL. Koss MA. Selling JA. Human duodenal mucosal bicarbonate secretion; evidence for basal secretion and stimulation by hydrochloric acid and a synthetic prostaglandin $\mathrm{E}_{1}$ analogue. Gastroenterology 1986; $91: 370-8$.
10 Isenberg JI, Sellig JA. Hogan BA, Koss MA. Impaired duodenal mucosal bicarbonate secretion in patients with duodenal ulcer. N Engl J Med 1987; 316: 374-9.

11 Wicks T, Clain D. A guide wire for rapid jejunal biopsies with the Crosby capsule. Gut 1972; 13: 571 .

12 Schmitt JR, Wood CM, Socrgel KH. A method for rapid placing of small intestinal perfusion tubes. Gut 1974; 15: 227-8.

13 Stern AI, Hogan DL. Isenberg JI. A new method for quantitation of ion fluxes across in vivo human gastric mucosa. Gastroenterology 1984; 86: 60-70.

14 Nimbratt C. Knutson L. Flemström G. Determination of bicarbonate secretion in gastrointestinal fluids [Abstract]. Scand J Gastroenterol 1988; 23 [suppl 145]: 106.

15 George JD. New clinical method for assuring the rate of gastric emptying: the double sampling test meal. Gut 1968: 9: 237-42.

16 Larsson LE. Non-labelled $B_{12}$ as a dilution indicator in GI research. Scand J Clin Lab Invest 1966: 18: 53.5-9.

17 Pelot D, Grossman MI. Distribution and fate of pancreatic enzymes in small intestine of the rat. $A m J$ Physiol 1962; 202: 285-8.

18 Bergmeyer HU, ed. Methods of enzymatic analysis. Weinheim, GFR: Verlag Chemic, 1983; Vol I: 10-4.

19 Flemström G, Garner A. Gastroduodenal $\mathrm{HCO}_{3}$ transport: characteristics and proposed role in acidity regulation and mucosal protcction. Am J Physiol 1982; 243: 18.3-93.

20) Quigley EMM. Turnberg LA. $\mathrm{pH}$ of the microclimate lining human gastric and duodenal mucosa in vivo. Studies in control subjects and in duodenal ulcer patients. Gastroenterology 1987; 92: 1876-84.

21 Rune SJ. Acid-Base parameters of duodenal contents in man. Gastroenterology 1972; 62: 533-9.

22 Harmon JW, Woods M, Gurli NJ. Different mechanisms of hydrogen ion removal in stomach and duodenum. Am J Physiol 1978; 235: 692-8.

23 Fändriks L, Jönson C, Nylander O, Flemström G. Neural influences on gastroduodenal $\mathrm{HOC}_{3}$ secretion. In: Szabo S, ed. Ulcer disease: new aspects of pathogenesis and pharmacology. Boca Raton: CRC Press, 1989. (In press).

24 Flemström G, Knutson L, Kivilaakso E. The mucus bicarbonate barrier and its role in gastroduodenal mucosal protection. In: Menge H. Gregor M. Tytgat GNJ, Marshall BJ, cds. Campylobacter pylori. Berlin: Springer Verlag, 1988: 69-77.

25 Forsell H, Olbe L. Effects of fundic distension on gastric bicarbonate secretion in man. Scand J Gastroenterol 1987; 22: 627-33.

26 Konturek SJ, Thor P. Relation between duodenal alkaline secretion and motility in fasted and sham-fed dogs. Am J Physiol 1986; 251: 591-6.

27 Konturek SJ, Kwiecien N, Obtulowics W. et al. Vagal cholinergic control of gastric alkaline secretion in normal subjects and duodenal ulcer patients. Gut 1987; 28: 739-44.

28 Nylander O, Flemström G. Effects of alphaadrenoceptor agonists and antagonists on duodenal surface epithelial $\mathrm{HCO}_{3}$ secretion in the rat in vivo. Acta Physiol Scand 1986; 126: 433-41. 
29 Jönsson C, Fändriks L. Electrical stimulation of the splanchnic nerves inhibits duodenal $\mathrm{HCO}_{3}$ secretion in the rat via activation of $\alpha_{2}$ adrenoreceptors. Am J Physiol 1989. (In press).

30 Jönsson C, Tunbäck-Hanson P, Fändriks L. Splanchnic nerve activation inhibits the increase in duodenal $\mathrm{HCO}_{3}$ secretion induced by luminal acidification in the rat. Gastroenterology 1989; 96: 45-9.

31 Flemström G. Effects of catecholamines, $\mathrm{Ca}^{++}$and gastrin on gastric $\mathrm{HCO}_{3}{ }^{-}$secretion. Acta Physiol Scand 1978 [suppl] Gastric ion transport: 81-90.

32 Durbin T, Rosenthal L, McArthur K, Anderson D, Dharmsathaphorn K. Clonidine and lidamine (WHR-1142) stimulate sodium and chloride absorption in the rabbit intestine. Gastroenterology 1982; 82: 1352-8.
33 Granstam SO, Flemström G, Nylander O. Bicarbonate secretion by the rabbit duodenum in vivo; effects of prostaglandins, vagal stimulation and some drugs. Acta Physiol Scand 1987; 131: 377-85.

34 Brandsborg $\mathrm{O}$, Brandsborg $M$, Lövgreen $N$. Christensen N. Increased plasma noradrenaline and serum gastrin in patients with duodenal ulcer. Eur J Clin Invest 1978; 8: 11-4.

35 Becker C, Andersen D, Kronborg O, Madsen P. Johansen T. Christiansen L. Plasma catecholamine and scrum concentrations during sham feeding. Life Sci 1983; 32: 257-67.

36 Menguy R, Masters YF. Mechanism of stress ulcer. Influence of alpha-adrenergic blockade on stress ulceration and gastric mucosal energy metabolism. Am J I ig Dis 1978; 23: 493-7. 